\title{
Communication \\ What Should Farmers' Rights Look Like? The Possible Substance of a Right
}

\author{
Kamalesh Adhikari ${ }^{1}$, Edwin Bikundo ${ }^{2}$, Xan Chacko ${ }^{3}$, Susannah Chapman ${ }^{1}$, Fran Humphries ${ }^{4}$, Hope Johnson ${ }^{4}$, \\ Evan Keast $^{5}$ (D), Charles Lawson ${ }^{2}{ }^{*} \mathbb{D}$, Justin Malbon ${ }^{2}$, Daniel Robinson ${ }^{6}$, Michelle Rourke ${ }^{2}$ (D), Jay Sanderson ${ }^{7}$ (D) \\ and Kieran Tranter 4
}

check for

updates

Citation: Adhikari, K.; Bikundo, E.; Chacko, X.; Chapman, S.; Humphries, F.; Johnson, H.; Keast, E.; Lawson, C.; Malbon, J.; Robinson, D.; et al. What Should Farmers' Rights Look Like? The Possible Substance of a Right. Agronomy 2021, 11, 367. https:// doi.org/10.3390/agronomy11020367

Academic Editors: Niels P. Louwaars and Bram de Jonge

Received: 14 December 2020

Accepted: 14 February 2021

Published: 18 February 2021

Publisher's Note: MDPI stays neutral with regard to jurisdictional claims in published maps and institutional affiliations.

Copyright: (c) 2021 by the authors. Licensee MDPI, Basel, Switzerland. This article is an open access article distributed under the terms and conditions of the Creative Commons Attribution (CC BY) license (https:/ / creativecommons.org/licenses/by/ $4.0 /)$.
1 UQ Law School/School of Social Science, University of Queensland, St Lucia, QLD 4072, Australia; k.adhikari@law.uq.edu.au (K.A.); susannah.chapman@uq.edu.au (S.C.)

2 Griffith Law School, Griffith University, Southport, QLD 4222, Australia; e.bikundo@griffith.edu.au (E.B.); justin.malbon@gmail.com (J.M.); m.rourke@griffith.edu.au (M.R.)

3 Department of Women's and Gender Studies, Wellesley College, Wellesley, MA 04281, USA; xchacko@wellesley.edu

4 School of Law, Queensland University of Technology, Brisbane, QLD 4000, Australia; fran.humphries@qut.edu.au (F.H.); h2.johnson@qut.edu.au (H.J.); k.tranter@qut.edu.au (K.T.)

5 Faculty of Humanities and Social Sciences, University of Queensland, St Lucia, QLD 4072, Australia; e.keast@uqconnect.edu.au

6 Faculty of Arts and Social Sciences, University of New South Wales, Kensington, NSW 2052, Australia; d.robinson@unsw.edu.au

7 School of Law and Society, University of the Sunshine Coast, Maroochydore DC, QLD 4558, Australia; jsander4@usc.edu.au

* Correspondence: c.lawson@griffith.edu.au; Tel.: (+61)-7-5552-7249

Abstract: Farmers' Rights formally appeared in the International Treaty on Plant Genetic Resources for Food and Agriculture (ITPGRFA) as a means of recognising the past, present, and future contributions of farmers in conserving, improving, and making available the plant genetic materials that are important for food and agriculture. Discussions have been underway under the auspices of the ITPGRFA's Governing Body with the recent Ad Hoc Technical Expert Group on Farmers' Rights (AHTEG-FR) collecting together views, experiences, and best practices to produce an inventory and options for encouraging, guiding, and promoting the realisation of Farmers' Rights. While this is useful, this article reports on the outcomes of a workshop that applied a different methodology. Our purpose was to identify what could be and should be the substance of Farmers' Rights so that the policy substance drives the implementation rather than the AHTEG-FR's retro-fitting Farmers' Rights to existing views, best practices, and measures. The contribution of this article is to develop and set out a list of possible substantive Farmers' Rights as a contribution and foundation for further consultations and negotiations.

Keywords: Farmers' Rights; ITPGRFA; justice; equity; AHTEG-FR; substantive rights

\section{Introduction}

Farmers' Rights formally appeared in law as an element of the Food and Agriculture Organization of the United Nations' (FAO, Rome, Italy) International Treaty on Plant Genetic Resources for Food and Agriculture (ITPGRFA, Rome, Italy) (Table 1) (Article 9). The conception of "Farmers' Rights" is to recognise the past, present, and future contributions of farmers in conserving, improving, and making available the genetic materials used in agriculture (Preamble and Article 9.1), as distinct from the "Farmers' Privilege" to save, reuse, and exchange seeds set out in the International Union for the Protection of New Varieties of Plants (UPOV, Geneva, Switzerland) 1991 (Article 15.2) and UPOV 1978 (Article 5). In an attempt to address Farmers' Rights, some countries have adopted specific legislation schemes addressing Farmers' Rights (e.g., The Protection of Plant Varieties and 
Farmers' Rights Act 2001 (India)), while others have identified elements of their laws that support Farmers' Rights (e.g., The Protection of New Plant Varieties Act of 2004 (Malaysia)), and others have signalled an intention to adopt such laws [1] (p. 4), [2] (para. 9 and Annex 1), [3] (pp. 133-134). Considerable work has also been undertaken by the ITPGRFA's Governing Body and committees to identify the likely form(s) of Farmers' Rights [4] (para. 39 and Appendix B.6 (Resolution 6/2019)), [5] (para. 34 and Appendix A.7 (Resolution 7/2017)), [6] (para. 34 and Appendix A.5 (Resolution 5/2015)); [7] (para. 39 and Appendix A.8 (Resolution 8/2013)), [8] (para. 29 and Appendix A.6 (Resolution 6/2011)). Despite this work, the substance of Farmers' Rights remains uncertain and contested.

Table 1. The International Treaty on Plant Genetic Resources for Food and Agriculture (ITPGRFA), Preamble, and Article 9 (Farmers' Rights).

ITPGRFA ITPGRFA Text

Affirming that the past, present, and future contributions of farmers in all regions of the world, particularly those in centres of origin and diversity, in conserving, improving and making available these resources, is the basis of Farmers' Rights.

Preamble Affirming also that the rights recognized in this Treaty to save, use, exchange and sell farm-saved seed and other propagating material, and to participate in decision-making regarding, and in the fair and equitable sharing of the benefits arising from, the use of plant genetic resources for food and agriculture, are fundamental to the realization of Farmers' Rights, as well as the promotion of Farmers' Rights at national and international levels.

The Contracting Parties recognize the enormous contribution that the local and indigenous communities and

Article 9.1 farmers of all regions of the world, particularly those in the centres of origin and crop diversity, have made and will continue to make for the conservation and development of plant genetic resources which constitute the basis of food and agriculture production throughout the world.

The Contracting Parties agree that the responsibility for realizing Farmers' Rights, as they relate to plant genetic resources for food and agriculture, rests with national governments. In accordance with their needs and priorities, each Contracting Party should, as appropriate, and subject to its national legislation, take measures to protect and promote Farmers' Rights, including:

Article 9.2 protection of traditional knowledge relevant to plant genetic resources for food and agriculture; the right to equitably participate in sharing benefits arising from the utilization of plant genetic resources for food and agriculture; and the right to participate in making decisions, at the national level, on matters related to the conservation and sustainable use of plant genetic resources for food and agriculture.

Article 9.3 Nothing in this Article shall be interpreted to limit any rights that farmers have to save, use, exchange and sell farm-saved seed/propagating material, subject to national law and as appropriate.

The current lacuna in discussions about Farmers' Rights at the ITPGRFA forums reflects a stalemate about how to actually deal with Farmers' Rights within the framework of the broad and indeterminate text of the ITPGRFA. There appear to be two perspective extremes and a gradient of other perspectives between these two positions based around "options" and "guidelines" [9] (paras. 18-22), although formal positions have not yet crystallised [4] (para. 39 and Resolution 6/2019)). One perspective seeks options for national governments about "one thing that can be chosen from a set of possibilities" or "the freedom to make a choice" and the other perspective guidelines to be promulgated by the ITPGRFA's Governing Body about "what should be done" (see [10] (paras. 5-8)). The diplomatic compromise at this stage between these perspectives has been to agree to "[p]roduce an inventory of national measures" and "[b]ased on the inventory, develop options for encouraging, guiding and promoting the realization of Farmers' Rights" within the confines of "Farmers' Rights as set out in Article 9 of the [ITPGRFA]" [4] (para. 39 and Appendix B.6 (Resolution 6/2019, para. 7)), [5] (para. 34 and Appendix A.7 (Resolution $7 / 2017$, Annex, para. 1)). The outcome, so far, is a partially completed inventory of measures and options according to agreed categories of existing views, best practices, and measures that relate generally to farmers with a focus on the form of the reporting 
documents and not the actual substance of Farmers' Rights (see [9] (Annexes 3 and 4)). This article is not intended to duplicate these efforts. Rather, our purpose is to apply a different approach and instead of asking what are the current policies, measures, projects, and activities that promote Farmers' Rights, we ask what could and should be the substance of Farmers' Rights? To do this, we convened a workshop at Griffith University, Australia, in February 2020 to explore important definitions (e.g., "farmer") and list substantive Farmers" Rights, and this article reports on the outcomes of the workshop. The workshop comprised academics from south east Queensland, Australia universities with a range of disciplinary interests. This article is a consensus statement of the workshop outcomes.

Before reporting on the workshop outcomes, the article provides an overview of the ITPGRFA's text about Farmers' Rights and the developments after the ITPGRFA took effect both within the ITPGRFA's Governing Body and in a range of consultations. Then follows the outcomes of the workshop addressing the substance of Farmers' Rights and listing a range of possible rights in appropriate rights language that could be a framework for future consultations and negotiations about Farmers' Rights.

\section{The ITPGRFA's Farmers' Rights}

The text of the ITPGRFA's Farmers' Rights provisions was a negotiated compromise (see [11] (pp. 2-7), [12] (p. 604)) and only requires that national governments "in accordance with their needs and priorities ... should, as appropriate, and subject to its national legislation, take measures to protect and promote Farmers' Rights" (Article 9.2) (Table 1). The text suggests in a non-exhaustive list that Farmers' Rights could include traditional knowledge, participation in benefit-sharing, and participation in decision-making (Article 9.2). The ITPGRFA is silent on its relationship with other international agreements, except for some preambular statements suggesting that the ITPGRFA as a later agreement does not limit a national government's existing obligations under other international agreements (Preamble; [13] (p. 447)). This means that national governments implementing Farmers' Rights will need to respect their existing international commitments on human rights, trade, intellectual property, and the like, and develop measures for implementing Farmers Rights within their national jurisdictions [11] (p. 1), [13] (p. 447). Other provisions in the ITPGRFA make specific provision for farmers that might contribute to Farmers' Rights in the governance arrangements for the ITPGRFA: that farmers share any benefits from using materials in the ITPGRFA's Multilateral System (Article 13.3) and when dealing with the ITPGRFA's financial resources that priority should be given to farmers in developing countries (Article 18.5).

Despite these very limited obligations in the ITPGRFA, Farmers' Rights remains an important issue for many of the Contracting Parties (e.g., [4] (para. 39 and Resolution 6/2019)). Some Contracting Parties consider their existing national measures are already consistent with their commitments under international and other laws, such as the kinds of rights already broadly recognised in the United Nations' Universal Declaration of Human Rights, International Covenant on Civil and Political Rights, International Covenant on Economic, Social and Cultural Rights, Convention on the Elimination of All Forms of Discrimination against Women, Declaration on the Rights of Peasants and Other People Working in Rural Areas, Declaration on the Rights of Indigenous Peoples, and so on. For these countries Farmers' Rights are already determined according to the national measures that have been implemented in accordance with their international commitments and that further measures are not expressly required. For example, Australia has stated that "The rights of Australian farmers, in the context of the objectives of Article 9 [of the ITPGRFA], are established under a broad legislative framework that provides a comprehensive set of intellectual, property and legal rights, including common law rights" [1] (p. 3). There remains disagreement among the Contracting Parties, however, about how to address these Farmers' Rights obligations as some countries are seeking some more formal obligations and this is addressed next in the context of developments under the ITPGRFA. 


\section{The Post-ITPGRFA Developments}

Governing Body sessions have addressed:

(a) The importance of Farmers' Rights [14] (para. 54 and Appendix N (p. 3)) and collecting views and experiences from Contracting Parties [15] (para. 75 (Resolution 2/2007, [vii] and [viii] (p. 13)), [16] (para. 49 and Appendix A.6 (Resolution 6/2009, paras. 3 and 4 (p. 34))), [8] (para. 29 and Appendix A.6 (Resolution 6/2011, para. 2 (p. 46))), [7] (para. 39 and >Appendix A.8 (Resolution 8/2013, para. 1)), [6] (para. 34 and Appendix A.5 (Resolution 5/2015, para. 1)).

(b) Implementing funding arrangements through a Funding Strategy (see [14] (para. 11 (Resolution 1/2006)) ) and subsequently formulating a Strategic Plan ([16] (para. 30 and Appendix A.3 (Resolution 3/2009, Annex 1)), [15] (para. 52)) to distribute the funds available under the ITPGRFA (see [16] (para. 30 and Appendix A.3 (Resolution $3 / 2009$, p. 14)); see also $[17,18])$.

(c) Funding a range of projects in developing countries (see [19,20]; and so on).

(d) Providing financial and technical support (where available) to national government seeking to realise Farmers' Rights [8] (para. 29 and Appendix A.6 (Resolution 6/2011, paras. 4 and 9 (p. 46))).

The Governing Body's Seventh Session then decided to establish an Ad Hoc Technical Expert Group on Farmers' Rights (AHTEG-FR) and seek the views of Contracting Parties and all relevant stakeholders, especially farmers' organisations, about their views, experiences and best practices as an example of possible options for national implementation of Farmers' Rights [5] (para. 34 and Appendix A.7 (Resolution 7/2017, paras. 7 and 8)). The AHTEG-FR convened to produce an inventory of national measures based on the submitted materials from Contracting Parties and stakeholders, and based on the inventory, to develop options for encouraging, guiding, and promoting the realisation of Farmers Rights [5] (para. 34 and Appendix A.7 (Resolution 7/2017, para. 7 and Annex)). The AHTEG-FR's first meeting noted:

"The [AHTEG-FR] acknowledged that the responsibility for realising Farmers' Rights, as they relate to plant genetic resources for food and agriculture, rests with national governments and this could be achieved through the adoption of national measures. It was noted that a variety of measures, including legal, financial, political and technical, could contribute towards this goal. It was recognized that while there has been some advancement in the discussions of Farmers' Rights under the [ITPGRFA], there was room for further progress in its implementation within the context of each Contracting Party". [21] (para. 8)

The outcome of the first meeting was essentially to structure the reporting document based around the materials submitted by Contracting Parties and all relevant stakeholders [21] (paras. 10, 11 and 15 and Appendix 4). The second meeting again focussed only on the structure and form of the inventory, agreeing that the main purpose of the inventory was to produce a catalogue of categories of the range of measures and practices [9] (para. 9). In starting to consider options, the second meeting then decided to list these options under the categories previously agreed for the inventory [9] (para. 19). The outcome of these meetings was a partially completed document setting out the form of an inventory of measures and options according to agreed categories (see [9] (Annexes 3 and 4)). Unfortunately, there was no consideration of the likely substance of Farmers' Rights at either meeting.

In addition to the formal Governing Body meetings and related formal processes like the AHTEG-FR, there have been a range of consultations responding to the invitations in Governing Body resolutions to convene meetings [5] (para. 34 and Appendix A.7 (Resolutions 7/2017, para.5)), [6] (para. 34 and Appendix A.5 (Resolution 5/2015, para. 6)), [7] (para. 39 and Appendix A.8 (Resolution 8/2013, para. 8)) [8] (para. 29 and Appendix A.6 (Resolution 6/2011, paras. 3 and 4)), [16] (para. 49 and Appendix A.6 (Resolution $6 / 2009$, para. 3)). These started with the Informal International Consultation on Farmers' Rights in 2007 [22]. There were 27 participants invited in their personal capacities from 20 
countries in different regions and drawn from governments, non-government organisations (NGOs), international organisations, research institutions, and other private and public institutions [22] (p. 13). The main outcomes were to recommend possible measures that the Governing Body could take to realise Farmers' Rights including:

(a) Giving priority to the implementation of the Farmers' Rights and other provisions that play an important role for their implementation.

(b) Facilitating the involvement of farmers' organisations in the Governing Body's and Secretariat's work.

(c) Encouraging the Contracting Parties to submit reports on the realisation of Farmers' Rights in their countries.

(d) Providing guidance and assistance to Contracting Parties in their implementation of Farmers' Rights.

(e) Developing guidelines on the realisation of Farmers' Rights at the national level.

(f) Mobilising funds within the funding strategy to facilitate the implementation of Farmers' Rights.

(g) Organising a world forum on Farmers' Rights to create awareness and encourage the sharing of experiences on progress made and any remaining challenges [22] (pp. 14-15).

The consultation also identified a number of issues that could be addressed to realise Farmers' Rights, for example, by promoting awareness on the importance of Farmers' Rights and related issues, providing space for farmers' customary practices related to plant genetic resources for food and agriculture, linking the realisation of Farmers' Rights to other measures such as the implementation of the Global Plan of Action for the Conservation and Sustainable Use of Plant Genetic Resources for Food and Agriculture, national commitments, international co-operation and technical assistance, and with benefit-sharing and the funding strategy, recognising the diversity of seed production and distribution systems, reporting back on what material has been provided to farmers by gene banks, and collecting information on materials and associated knowledge obtained from farmers and used by private and public organisations in breeding processes [22] (pp. 15-16).

The next significant meeting was the Global Consultation on Farmers' Rights in 2010 comprising a conference and an email survey [23] (Annex 1). There were 177 experts and stakeholders from 46 countries, including representatives from farmer organisations, government institutions, the seed industry, NGOs, intergovernmental organisations, researchers, and so on [23] (para. 3 and Annex 1, paras. 4 and 6]). The report from the consultation was a "consensus document" so the outcomes may not properly reflect the views of those participating in the consultation [23] (para. 4). The main outcomes from the email survey included the need for guidance and support from the Governing Body to develop or adjust national legislation, policies, strategies, and programmes for the realisation of Farmers' Rights, saving traditional knowledge from becoming lost, measures to document and encourage the sharing of traditional knowledge, measures to avoid misappropriation of traditional knowledge, scaling up experiences to the national level from benefit-sharing involving local seed banks, seed exchange networks, participatory plant-breeding projects, registries of crop genetic resources and value-adding projects, strengthening informal seed systems, greater awareness among farmers and decisionmakers about Farmers' Rights and ensuring farmers' participate in decision-making, and technical and financial support for the realisation of Farmers' Rights [23] (Annex 1, para. 5). The main outcomes from the conference were regional grouping recommendations (see [23] (Annex 1, paras. 10-70)) and joint recommendations that the Governing Body should:

(a) Prioritise technical and financial support to national governments in the realisation of Farmers' Rights.

(b) Improve national legislation to allow for balanced regulation for all types of seeds.

(c) Ensure the full participation of all stakeholder groups in Governing Body deliberations.

(d) Mainstream gender in the realisation of Farmers' Rights. 
(e) Develop voluntary guidelines on the national implementation of Farmers' Rights and related provisions addressing:

(i) The implications for farmers' livelihoods and other social, economic, and environmental issues.

(ii) Formal and local seed systems.

(iii) Promoting understanding and awareness of Farmers' Rights at all levels, including decision makers and farmers.

(iv) The protection and promotion of traditional knowledge including livelihoods, cultures, and places.

(v) Promoting collaboration between local communities and scientists.

(vi) Encouraging the mutual exchange of knowledge and practices.

(vii) Promoting the right of farmers to directly benefit from the conservation and development of their plant genetic resources for food and agriculture.

(viii) Exploring the possibility of establishing national benefit-sharing funds.

(ix) Promoting equality between formal scientific and local community knowledge [23] (Annex 1, paras. 72-89).

In 2016, the Government of Indonesia invited the Government of Norway to co-host a Global Consultation on Farmers' Rights pointing to the Governing Body's invitation for initiatives to convene regional workshops and other consultations [6] (para. 34 and Appendix A.5 (Resolution 5/2015, para. 6)). The consultation brought together 95 participants from 37 countries in Africa, Asia, Europe, Latin America and the Caribbean, the Near East, North America, and Southwest Pacific [24] (p. 8) (see also [25,26]). Again, there was no consensus at the consultation, so the report was prepared by the Co-chairs with their summary of the recommendations "reflecting their interpretation of discussions at the consultation" [24] (p. 30). The Co-chair's summary identified various possibilities for Farmers' Rights such as:

(a) Institutional measures-The development of legislation, capacity, and other institutional frameworks necessary for the realisation of Farmers' Rights, the formulation of voluntary guidelines on the realisation of Farmers' Rights at national level, the organisation of biannual global consultations on the realisation of Farmers' Rights, the development of procedures to strengthen the participation of representatives of farmers and local and indigenous communities, and the designation of an annual international day to celebrate farmers of all regions who contribute to the conservation and sustainable use of crop genetic resources for food and agriculture and to the achievement of food security.

(b) Practical measures-The sharing of electronic copies of legislation and other regulations that relate to the implementation of Farmers' Rights, the extension of organisational and financial support to facilitate the participation of farmers' organisations and other relevant stakeholders, the promotion of participatory approaches such as community seed banks, community biodiversity registries, participatory plant breeding, and seed fairs as tools for realising Farmers' Rights, and the provision of technical and financial support to national governments and organisations for the realisation of Farmers' Rights.

(c) Legal measures-The revision of seed laws, intellectual property laws and other legislation that may limit the legal space or create undue obstacles for the realisation of Farmers' Rights, and the introduction of measures, including legislation and policies, to protect and promote traditional knowledge that is relevant to plant genetic resources for food and agriculture [24] (pp. 30-31).

Preceding and in preparation for the Global Consultation on Farmers' Rights and pointing to the Governing Body's invitation for initiatives to convene regional workshops [6] (para. 34 and Appendix A.5 (Resolution 5/2015, para. 6)), the Stakeholders' Consultation for Africa was convened in 2016 [27]. The consultation was attended by 59 participants representing Contracting Parties, farmers, and farmers' organisations, civil 
society organisations, regional organisations, research institutions and academia [27] (p. 3). The consultation posited that Farmers' Rights were not being implemented because of:

" ... the weak and sometimes contradicting policy and legislation; the expansion of intellectual property to farmer seed systems; the lack of financial resources for the development of support structures; the lack of common strategy or collaboration between and among various sectors and stakeholders; unwillingness of decision-makers to [undertake] Farmers' Rights' implementation; and the lack of awareness and real understanding of what constitute Farmers' Rights". [27] (p. 3)

In understanding Farmers' Rights, the consultation proposed a definition for the African context, accepting that there was no broad consensus on the definition from the existing international instruments:

"Farmers' Rights in the African context shall consist of the customary rights that farmers have had as stewards of agro-biodiversity to save, use, exchange, grow, share, develop and maintain plant varieties, of their legitimate right to be rewarded and supported for their contribution to the development of commercial varieties of plants, to participate in decision-making on issues that may affect these rights. Farmers' Rights must be viewed as collective rights and not as an individual right". [27] (p. 4)

The consultation then identified a number of contentious issues related to Farmers' Rights without specifically addressing the content of Farmers' Rights. Importantly, the consultation was ordered according to the elements of Farmers' Rights set out in the ITPGRFA [27] (pp. 4-6). Seed and intellectual property laws were considered to undermine Farmers' Rights to save, use, exchange and sell farm-saved seeds and other propagating material [27] (p. 5). Seed laws prevented farmers from commercialising their indigenous as well as locally saved and used plant varieties, and intellectual property laws (specifically plant breeder's rights laws) limited farmers' ability to save, use, exchange, and sell the farm-saved seed of protected varieties [27] (p. 5). Traditional knowledge was considered to be lost, and it was emphasised that measures were required to incentivise farmers, for example, through the payment of royalties for their knowledge about plant varieties "in the same way commercial breeders receive royalties for their protected varieties" [27] (p. 5). The consultation also considered that "farmers should be recognized as innovators" and that "they should benefit equitably with the providers of technology" [27] (p. 6). The consultation also recognised that farmers should participate in decision-making about implementing Farmers' Rights, including in processes that develop participatory plant breeding programs, seed laws and regulations, and variety release and registration systems [27] (p. 6). Additionally, the consultation addressed several key issues and concerns of the African farmers such as:

(a) the lack of supportive policy and legislative frameworks which protect smallholder farmer seed systems;

(b) lack of guidelines on on-farm seed production; and

(c) absence of supportive mechanisms for saving, selling, exchanging, and marketing of farmers' seeds [27] (p. 6).

Other concerns of the African farmers included the ambiguities surrounding the legal status of small holder farmers, non-recognition of their "intellectual rights", lack of measures to protect their own technologies, knowledge and innovations, lack of institutional support in relation to the implementation of their customary rights, lack of capacity building measures, absence of information and technology transfer to help them produce quality seed of local plant varieties, and lack of initiatives "to support initiatives such as: (i) integrated farmer seed systems through the value chain which include aspects of quality seed production, (ii) farmer-led agricultural research, (iii) on-farm seed multiplication, (iv) seed processing, (v) seed marketing in local niche markets, and (vi) seed storage in community seed banks" [27] (pp. 6-8). The consultation also noted that the implementation of 
Farmers' Rights was the responsibility of national governments and that "[t]his provision makes the implementation of Farmers' Rights uncertain and not being realized" [27] (p. 11). The consultation also identified a number of challenges and opportunities in implementing Farmers' Rights in Africa, including the lack of alignment of Farmers' Rights to other international conventions, fragmented institutional frameworks, poor institutional arrangements, disharmony among policies and legislation, and so on [27] (pp. 11-12). And, finally, the participants wanted guidelines for policy development, including guidance on how Farmers' Rights' can be effectively implemented [27] (p. 17).

Another consultation preceding and in preparation for the Global Consultation on Farmers' Rights, and also pointing to the Governing Body's invitation for initiatives to convene regional workshops [6] (para. 34 and Appendix A.5 (Resolution 5/2015, para. 6)), was the Quaker United Nations Office Farmers' Rights Consultation in 2016 [28]. The consultation was attended by 10 participants from NGOs, civil society organisations, academics, and government representatives [28] (pp. 4-5). The consultation outcomes recommended procedural and substantive messages. The procedural message was the need for ongoing consideration of lessons learned, key messages, and recommendations from consultations and an emphasis on dialogue between state delegates and farmers' organisations [28] (p. 6). The substantive message was that contrasting perspectives of Farmers' Rights had impeded the development of policies, legal instruments, and tools; agricultural development policies, trade policies, and research and development policies should incorporate Farmers' Rights; farmer-centric projects should be advanced; and a "Model Law on Farmers' Rights" needed to be drafted, adapted, and implemented in various contexts. Furthermore, the message was significant in calling for a greater effort to "geo-reference and register farmers' genetic resources and traditional knowledge and share oral and written information through social networking", and to consider the implications of the proliferation of trade agreements and the tying of financial support from government and philanthropic donors to policy measures that limit a country's flexibility to implement Farmers' Rights [28] (pp. 6-8). Most importantly, the consultation reported:

"The lack of a clear definition of Farmers' Rights does not have to be a problem. Though it may present a legal challenge, Farmers' Rights is a concept that extends beyond the provisions included in Article 9 and beyond the [ITPGRFA] with a scope that is limited to [plant genetic resources for food and agriculture]. The broader set of rights articulated within international human rights law pertaining to peasants and other people working in rural areas are relevant. There is significant scope for creative initiatives to seek to realise Farmers' Rights, broadly defined. For instance, linking Farmers' Rights to the protection and promotion of cultural heritage and diversity can enhance the visibility of small-scale farmers, their value, and the challenges they face". [28] (p. 8)

The ITPGRFA's Secretariat also conducted an online consultation in 2016 in response to the Governing Body's invitation for initiatives to convene regional workshops [29]. The consultation involved 166 respondents from 53 countries representing governments, NGOs, civil society organisations, the seed industry, research and academic institutions, farmers organisations, and indigenous communities [29] (para. 11). The questions were based on work by the Fridtjof Nansen Institute and framed around the elements of Farmers' Rights as they are presented in the ITPGRFA: the protection of traditional knowledge; the right to equitably participate in sharing benefits; the right to participate in making decisions; and any rights that farmers have to save, use, exchange and sell farm-saved seeds and other propagating material [29] (paras. 6 and 9 and Appendix 1 (Question 9)). Perhaps unsurprisingly, the responses favoured these elements of Farmers' Rights, although interestingly, approximately 12 percent of respondents considered these elements "less important" [29] (para. 12 and Figure 2). The survey did not consider Farmers' Rights more broadly than the elements set out in the ITPGRFA.

In 2016, the Governing Body's request to "invite [International Union for the Protection of New Varieties of Plants (UPOV)] and [the World Intellectual Property Organisation 
(WIPO)] to jointly identify possible areas of interrelations among their respective international instruments" was initiated [7] (para. 39 and Appendix A.8 (Resolution 8/2013, para. 3)) and the engagement continued [6] (para. 34 and Appendix A.5 (Resolution 5/2015, para. 12)) with a symposium held in 2016 [4] (para. 34 and Appendix A.7 (Resolution $7 / 2017$, para. 11)) (see also [30]). While there was no formal report, the proceedings revealed that the point of contention between Farmers' Rights and the UPOV is about the possibility of conflict - that plant breeder's rights consistent with UPOV (and the World Trade Organisation's Agreement on Trade-related Aspects of Intellectual Property Rights (TRIPS)) may not be supportive of Farmers' Rights or may undermine those rights so they cannot be fully realised (e.g., [30] (p. 49)). The sites of these conflicts are the rights of farmers to save, use, exchange, and sell farm-saved seed and other propagating material; the misappropriation of traditional knowledge; the failure to give due recognition to the contribution of local and indigenous communities and farmers or acknowledge their continuing important role in the development of plant genetic resources for food and agriculture; the use of plant materials by breeders without appropriate consent and benefit-sharing with the traditional farmers and their communities; and the failure to facilitate farmers' participation in making decisions (see [30] (pp. 50-58)). The counter to these assertions of conflict is that Farmers' Rights are a responsibility of national governments and they have to balance their responsibilities according to their national needs and priorities (see [30] (pp. 28-29)). Further, the positively framed ITPGRFA Farmers' Rights elements to protect traditional knowledge, equitably participate in benefit-sharing and participate in decisionmaking (Article 9.2) are separate to the negatively framed right to allow farmers to save, use, exchange, and sell farm-saved seed and other propagating material (Article 9.3), with the former "as appropriate, and subject to national law" (Article 9.2) meaning that the national laws do not necessarily have to fulfil these measures [30] (p. 29). As a consequence, these decisions are matters for national governments to make balancing the ITPGRFA, TRIPS, UPOV, and other commitments [30] (pp. 34-35).

The Secretariat of the International Planning Committee for Food Sovereignty and the Community Technology Development Trust organised regional consultations in Africa, Asia, and Latin America and the Caribbean in 2018 (see [31]) and again pointed to the Governing Body's invitation for initiatives to convene regional workshops [5] (para. 34 and Appendix A.7 (Resolution 7/2017, para. 5)), [6] (para. 34 and Appendix A.5 (Resolution 5/2015, para. 6)). The African meeting involved 40 participants from 17 countries representing peasants, pastoralists, small-scale farmers, women's organisations, NGOs, and organisations active in food sovereignty [31] (p. 2). The outcome was to recommend the Governing Body facilitate drafting guidelines on the implementation of Farmers' Rights about protecting traditional knowledge, equitably participating in sharing benefits, participating in making decisions, the right to save, use, exchange, and sell seeds and the propagating material conserved on farm, and the rights to redress through "a mechanism that allows peasants and the organizations that support them, to claim for redress in case of violation of their rights" [31] (pp. 3-5).

The Asia and the Pacific meeting had 40 participants from 10 countries representing peasants and other small-scale farmers, Indigenous Peoples, and women's organisations being "smallholders, artisanal fisherfolk, pastoralists, forest dwellers, women and all the communities that produce food in agroecological ways and contribute to maintaining biodiversity" [31] (p. 6). The outcomes were to recognise the failure to appreciate the importance of insecurity in rights of tenure and ownership and women peasants' contributions in agriculture, and to emphasise that the principles of food sovereignty should underscore all considerations of Farmers' Rights- “that everyone and their communities have the right to culturally-appropriate and nutritious food produced in ecologically-sound ways, and the right to collectively determine our own food and agriculture systems" [31] (pp. 6-7). Farmers' Rights were then conceived in the context of cultural seed systems (being commons for the public good based on crop wild relatives and wild plants "in some cultural seed systems that are genetically related to cultivated crops that have been used 
since the beginnings of agriculture by [I]ndigenous [P]eoples and later by peasants" ([31] (p. 8)) and industrial seed systems (being "designed to bring profit via exclusivity, and/or are produced using ecologically-unsound and/or-sound practices for private gain" ([31] (p. 8)) with proposals based on these differences including:

(a) Recognise that Indigenous Peoples and peasants are the stewards of the parental lines of industrial seed varieties.

(b) That there should be no intellectual property, exclusive rights, or information restrictions on industrial seed varieties.

(c) Cultural seed systems, wild crop relatives, and wild plants must be in the control of Indigenous Peoples and peasants.

(d) Women peasants and other women working in rural areas should be supported.

(e) There must be compulsory disclosure of the Indigenous Peoples and peasants who are the stewards of parental lines of newly industrialised seeds.

(f) There must be no compulsory registration of seeds or sample deposits from cultural seed systems, that are themselves a legitimate method for seed identification.

(g) Farmers have the right to use, re-use, sow, re-sow, save, improve, select, exchange, share, sell, and propagate farm-saved seeds and traditional knowledge.

(h) Farmers have the right to timely and accurate information from governments about plant genetic resources for food and agriculture in local languages and through farmers' channels.

(i) Indigenous Peoples and peasants have the right to participation in all decision-making processes about plant genetic resources for food and agriculture at local, sub-national, national and regional levels and there should be at least $50 \%$ women participation.

(j) The management of benefit-sharing funds should directly involve farmers' organisations including Indigenous Peoples' and peasants' organisations at national, regional and global level [31] (pp. 8-11).

The Latin America and the Caribbean meeting involved 40 participants from 13 countries representing farmer, indigenous, women and pastoralist organisations [31] (p. 12). The outcome was to state some principles:

(a) Seeds as the heritage of peoples at the service of humanity and as collective rights.

(b) The important role and place of women.

(c) Respecting territoriality.

(d) The importance of Free, Prior, and Informed Consent before any initiative that may affect agricultural biodiversity, knowledge, autonomy and territories of local communities and Indigenous Peoples.

(e) The farmers' rights to rescue, protect, multiply, improve, select, conserve, use, exchange and sell their own seeds.

(f) That "traditional and ancestral systems of native and creole seed management should not be considered as 'informal systems', but they are customary rights and represent the main systems for the creation of agricultural biodiversity" [31] (p. 13).

In addition to adopting these principles, the consultation also proposed "the rejection of the industrial agriculture that includes the transgenic seeds and the massive use of agro-toxics" and the rejection of "the new breeding manipulated techniques proposed by the corporations, which include the new transgenic, synthetic biology, gene editing (CRISP-R), 'terminators' seeds and the genetic dematerialization of seeds" [31] (p. 14). The consultation also proposed that, in part:

(a) There be recognition that commercial, industrial, and uniform varieties come from native and peasants' seeds.

(b) Seed laws, patents, and other intellectual property systems needed reviewing and updating.

(c) Various rights needed to be respected such as participating in making laws implementing Farmers' Rights at the national level. 
(d) Registries should not include native and peasants' seeds except in the inventories of the communities according to their needs and controlled by them.

(e) Companies that commercialise commercial, industrial, and uniform seeds must pay benefits and peasant and indigenous organisations must participate in the management of these funds.

(f) Phytosanitary norms should not affect the exercise of Farmers' Rights.

(g) Free, Prior, and Informed Consent is necessary in discussion and decision-making [31] (pp. 14-15).

While the ITPGRFA's Governing Body and the various consultations have engaged a broad range of stakeholders and identified a diversity of issues and concerns, there remains some uncertainty about the possible substance of Farmers' Rights. Our workshop directly addressed this concern.

\section{The Substance of Farmers' Rights and Workshop Results on the Substance of Farmers' Rights}

The current workings of the AHTEG-FR are focussed on an inventory and options according to agreed categories (see [9] (Annexes 3 and 4)). The methodology of the AHTEG-FR has been to invite the submission from "Contracting Parties and relevant stakeholders" about their "views, best practices and measures for implementing Farmers' Rights" [9] (para. 1), [21] (paras. 10 and 11]). The likely outcome of the AHTEG-FR will be an inventory of existing best practices and measures that Contracting Parties and other stakeholders say could comprise Farmers' Rights within existing national government measures. Our workshop methodology, however, was different. Our purpose was to identify what could be and should be the substance of Farmers' Rights so that the policy substance drives the implementation rather than retro-fitting Farmers' Rights to existing views, best practices, and measures. Our methodology presumes Farmers' Rights are a new development as opposed to merely requiring implementation of already developed views, best practices, and measures, accepting that some of these views, best practices, and measures are substantive Farmers' Rights. While the workshop generated exhaustive consideration of what the category of a farmer could encompass, our lack of consensus about how a rights-based system "should" bestow rights represents a shared sensitivity towards the power and politics of a law based on identity. Who counts as a farmer matters if the rights afforded such an identity confers preferential treatment in any way.

Starting with a broad lens, the issues of Farmers' Rights are essentially matters of necessity and contingency. Take, for example, the full enjoyment of all human rights as an expressed right (see, e.g., UNDROP, Article 3). This essentially comprises a right to a legal personality (primary) and a right to non-discrimination (secondary). This also establishes a legal hierarchy with a superior enabling provision that allows laws to be made that give substance to the right and then a substantive right that is a limitation-in other words, a right for a farmer is a duty for non-farmers. A further important distinction is that Farmers' Rights need to be considered according to the division between rights to all that includes farmers and rights that are specific to farmers and exclude non-farmers. An example would be rights that apply to all including farmers although not specifically only farmers, such as "The right to life, liberty and security of person" (UDHR 1948, Article 3), and rights that apply only for farmers and not non-farmers such as "the right to determine their own food and agriculture systems" (UNDROP, Article 15.4).

Any instrument promulgating Farmers' Rights would, therefore, need to clearly decide whether it was about identifying rights that:

(a) Apply to all including farmers-Like the Universal Declaration of Human Rights "Everyone has the right to a standard of living adequate for the health and well-being of himself and of his family, including food" (UDHR 1948, Article 4).

(b) Apply to farmers that are also enjoyed by non-farmers-Like the Declaration on the Rights of Peasants and Other People Working in Rural Areas "Peasants and 
other people working in rural areas have the right to adequate food" (UNDROP, Article 15.1).

(c) Apply only to farmers (and not non-farmers) - Like the UNDRIP (2007) “Indigenous Peoples have the right to establish and control their educational systems and institutions providing education in their own languages" (UNDRIP 2007, Article 14.1).

Where an instrument is intended to apply to only farmers (and not non-farmers), then there needs to be a definition of "farmer" so that the grouping of farmer with the right can be distinguished from the non-farmer with the duty. In a diplomatic setting, definitions are a useful means of compromise and gaining broad endorsement although the result is that the object of the instrument tends to broaden so as to gain more agreement, but results in less specificity. For example, the Declaration on the Rights of Peasants and Other People Working in Rural Areas defines "peasant" as the object of the declaration:

"a peasant is any person who engages or who seeks to engage alone, or in association with others or as a community, in small-scale agricultural production for subsistence and/or for the market, and who relies significantly, though not necessarily exclusively, on family or household labour and other non-monetised ways of organising labour, and who has a special dependency on and attachment to the land".

\section{(UNDROP 2018, Article 1.1)}

The application of the Declaration is then broadened to address "other people working in rural areas", and this expands the reach to almost all humans, including "to any person engaged in artisanal or small-scale agriculture, crop planting, livestock raising, pastoralism, fishing, forestry, hunting or gathering, and handicrafts related to agriculture or a related occupation in a rural area" (UNDROP 2018, Article 1.2), "Indigenous Peoples and local communities working on the land" (UNDROP 2018, Article 1.3), "hired workers ... on plantations, agricultural farms, forests and farms in aquaculture and in agro-industrial enterprises" (UNDROP, Article 1.4), and so on. While broadly acceptable, the loss of specificity detracts from the power of recognising the right, as the group entitled to the right essentially includes almost all people outside a major city. Another approach is to leave the terminology undetermined, like the UNDRIP, that applies to "Indigenous Peoples" that are identified according to "Indigenous Peoples have the right to determine their own identity or membership" (UNDRIP, Article 33.1). In short, there are two distinct approaches: one defines a "farmer", so that the non-farmer is a clearly identifiable grouping, and the other leaves the definition open to be determined by those who seek to implement or claim Farmers' Rights.

The workshop identified the definition of "farmer" as a key legal issue in any discussions about Farmers' Rights. Unable to reach a consensus on any definition, the following sets out the range of views about how a definition might be found. The first step was to recognise the complex and integrated nature of farming in the world economy and that farming depends on engagement with a number of other key sectors in every economy. As such, there are a complex web of relationships around a "farmer" including economic rights (deposit holders, lenders, brokers, and so on), land and property rights, resource rights, and so on. While there were easily recognised differences between rich and high technology economies and poorer and low technology economies, there were some fundamental elements that were considered vital to enable all farming. These were considered to be labour, finance, breeding stock, and materials. These were generalised labels to capture the broader ideals that farming involved bringing labour to perform work together with the resources of finance to buy and pay; breeding stock to provide plants, animals, fungi, algae, and other biologicals; and materials to enable the labour, finance, and breeding stock to conduct the activity of farming. In this sense, materials broadly extends to land, water, fertilisers, tractors, pangas, and so on, as all the things necessary to do farm activity (except labour, finance and breeding stock). This is a generalisation, and other dimensions were obviously possible (such as government regulation, markets, weather, transport, and 
so on), although these identified matters were considered to be a useful basic minimum characterisation of the fundamental elements for the activity of farming.

This first step was considered important to then frame the next steps about whether the "farmer" was within or outside these integrated elements (Figure 1). Placing the "farmer" outside these other elements might help to identify the specific concerns of farmers relative to their engagement with these and other elements, while placing the "farmer" inside these other elements might help to clarify the synergies and overlaps between these different elements within the farming enterprise. For example, if a "farmer" is outside the finance element, then finance is something the farmer has to engage with as a financial institution, generally outside the farm and in a city, to borrow, repay, re-finance, and so on, to conduct the activity of farming, while inside this would be one of the on-farm tasks of the farmer to balance and negotiate with the other competing on-farm tasks. In other words, the farmer's relationship to the other elements necessary to conduct farming helps to set a frame of reference for the kinds of substantive rights a farmer might expect. Where finance is, for example, external to the farm, then there might be a right for a "farmer" and an obligation on a financial institution to address the right of that farmer. When elements are framed as external to the "farmer", the rights of farmers are much easier to identify and reduce to rights text. Importantly, however, is to accept that some elements can never be external to the farmer, such as the environment.

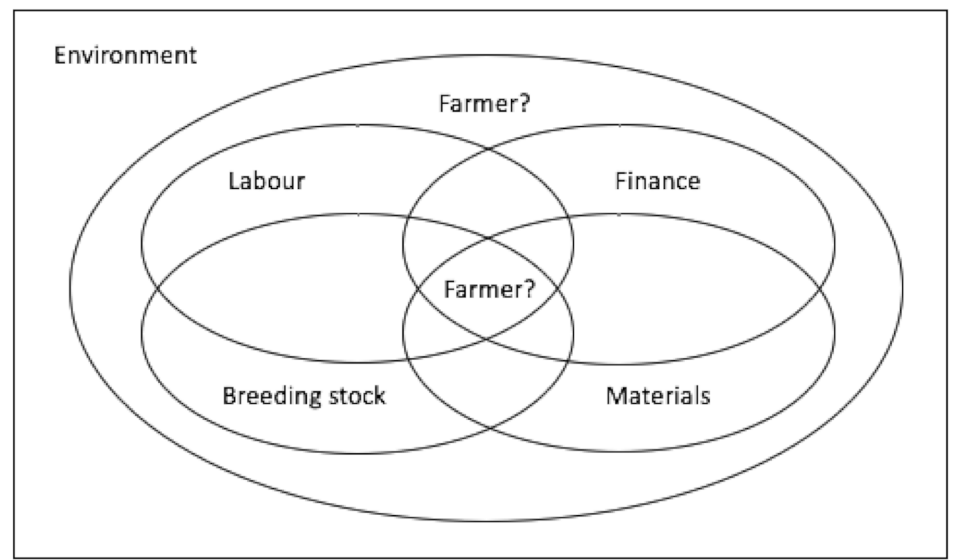

Figure 1. The first step in defining "farmer" was to recognise the complex and integrated nature of farming in the world economy, and that farming depends on engagement with a number of other key sectors in every economy. The question was then where to place a "farmer" within or outside this complex?

The next step was to consider the different ways a "farmer" might be defined. The workshop identified the following possible ways, noting that a satisfactory definition may require two or more ways to be combined for an effective definition:

(a) Legal entity-This approach to a definition bounds the "farmer" according to the legal entity that is carrying out the farming activity. The kinds of relevant legal entities, depending on the national laws, might be individuals, owners (of land, finance, resources, trusts, and so on), other legal statuses of humans (such as workers, lessees, life interest holders, and so on), and communities of humans and non-human legal entities (such as corporations, associations, co-operatives, partnerships, joint ventures, Indigenous Peoples, local communities, landscapes, river valleys, and so on). The relevant legal entity will then (most probably) need to be combined with another for a satisfactory definition, such as an activity, an activity and a region, a subject matter, a subject matter and a region, and so on.

(b) Activity-This approach defines the activity that is farming so that the entity carrying on that activity can be said to be a "farmer" recognising that farming is essentially agricultural (so growers, breeders, and conservers of plants), pastoral (so growers, 
breeders, and conservers of animals/fish), and forestry (so harvesters and conservers of forests) (but maybe not other activities like solar farming, wind farming, and so on). This is best illustrated by examples from current laws:

(i) The Protection of Plant Varieties and Farmers' Right Act 2001 (India)—This legislation defines "farmer" as "any person" who "cultivates crops by cultivating the land himself", "cultivates crops by directly supervising the cultivation of land through any other person", or "conserves and preserves, severally or jointly, with any person any wild species or traditional varieties or adds value to such wild species or traditional varieties through selection and identification of their useful properties" (Section 2(k)).

(ii) Income Tax Assessment Act 1997 (Australia)—This legislation provides a tax regime for farmers that conduct a "primary production business" that is defined as carrying on the business (being any profession, trade, employment, vocation or calling, but does not include an employee) of "cultivating or propagating plants, fungi or their products or parts (including seeds, spores, bulbs and similar things), in any physical environment", "maintaining animals for the purpose of selling them or their bodily produce (including natural increase)", "manufacturing dairy produce from raw material that you produced", "conducting operations relating directly to taking or catching fish, turtles, dugong, beche-de-mer, crustaceans or aquatic molluscs", "conducting operations relating directly to taking or culturing pearls or pearl shell", "planting or tending trees in a plantation or forest that are intended to be felled", "felling trees in a plantation or forest", and "transporting trees, or parts of trees ... felled in a plantation or forest to the place where ... they are first to be milled or processed or from which they are to be transported to the place where they are first to be milled or processed" (Section 995.1).

(c) Size of farm (business or enterprise) — Like the legal entities carrying out farming activities, the size of the farming enterprise might be important. As a generalisation, large commercial industrial farms have a different form to small, family conducted farms. The kinds of rights that might be relevant for a small, family conducted farm may need to be different to those afforded large commercial industrial farms. In this sense, the size of the enterprise might be a point of distinction, according to land area, value of land and resources, turnover of the business or enterprise, and so on.

(d) Region-Another approach is to draw distinctions between urban geographies and rural/farming geographies. This would involve an approach that would characterise regions by land use and have a deeming rule that determines at what point the percentage or ratio of agricultural land use makes a "farming" region. The critical categories would be between urban land use, farming land use, and wildness or low human land use. The strength of this approach is that it would allow all residents in farming regions to be regarded as a "farmer" regardless of their legal relationship to land and production assets, or whether they are primarily and principally engaged in agricultural practices or members of a broader community supporting, contributing, and benefiting from the region's farming practices. The weakness of this approach is it could miss significant and increasingly important urban farming practices, microfarming, and high-technology-enabled, urban-located agricultural productive enterprises.

(e) Livelihood, lifestyle, and occupation and activity -Where the activity approach takes an instrumentalist perspective-looking at the types of physical, productive tasks that can denote "farming" - an alternative approach is to emphasis the cultural experience of living through and with farming activities. Examples of this approach can be seen in the emphasis given to "embodying traditional lifestyles" [32] (para. 13) by the Commission of Human Rights subcommittee report into protection of the heritage of Indigenous People or in the notion of "conserving, improving and making available plant genetic resources" [33] (para. 108 (Resolution 5/89)) adopted by the FAO. In 
both, it is the human cultural context through which farming practices occurs that is emphasised. Such an approach could be achieved two ways:

(i) The simplest is to have "farmer" self-identify. This approach empowers individuals located in specific cultural contexts to declare their status. As an approach, it runs the risk of conflict where specific individuals claim to be farmers where the wider cultural or community expectation is that they are not. A different approach would be to focus on specific categories of livelihoods, lifestyles, and occupations that are culturally located and commonly understood as connected with farming, such as livelihoods like a subsistence farmer on community tenure lands or an occupation in the form of a business/enterprise where the activity of farming is carried out to earn an income. This approach would avoid the potential conflict in the self-identification approach, but due to its being located within existing cultural expectations, it could have difficulties with inclusive identification of innovated and disrupted agricultural practices.

The workshop also addressed the question of whether Farmers' Rights should be framed within the ambit of the ITPGRFA? The consideration was that by limiting the potential reach of Farmers' Rights to the ITPGRFA and focussing on the subject matter of the ITPGRFA, such as plant genetic resources for food and agriculture, there was likely to be a more real and effective outcome for farmers seeking justice from access to plant genetic resources and benefit-sharing regimes. The issues here were about, for example, the early focus of Farmers' Rights discussions on the potential for plant breeder's rights, like those consistent with UPOV, to undermine Farmers' Rights to save, use, exchange, and sell farm-saved seed and other propagating material (e.g., [34]). The concern was that by limiting the discussion to the ambit of the ITPGRFA and Article 9, these kinds of complex policy issues could be addressed and resolved. Again, there was no consensus, and different participants saw benefit in both narrow and broad approaches to Farmers Rights discussions. The main considerations were that the ITPGRFA had too narrow a focus, and a broader conception opened up the potential of other forums to take up the Farmers' Rights issues (such as the Human Rights Commission), that the broader concerns of farmers beyond plants and seeds needed to be addressed, and that the limited capacity of the current ITPGRFA arrangements may not be sufficient to deal with all the complex dynamics of Farmers' Rights.

The remaining question is the likely substance of Farmers' Rights. A useful starting point was to look to the comprehensive consultative processes in developing the Peasant Rights' Charter in the 1990-2000s leading to the United Nations' Declaration on the Rights of Peasants and Other People Working in Rural Areas [35] (pp. 55-62). A significant milestone was the Human Rights Council Advisory Committee report of the advancement of the rights of peasants and other people working in rural areas [36]. Of particular interest that study addressed the vulnerable groups working in rural areas that are subject to discrimination, the causes of discrimination and vulnerability of peasants and other people working in rural areas, and the protection of the rights of peasants and other people working in rural areas under international human rights law [36] (paras. 9-62). Add to this the useful articulation in rights language of various rights set out in the Declaration on the Rights of Peasants and Other People Working in Rural Areas, and then adding matters identified from the ITPGRFA's Governing Body and the various consultations, the outcome is a basic framework for the possible substance of Farmers' Rights. To make this listing more comprehensible, a basic structure to determining the substance of Farmers' Rights was addressed under the following headings: livelihood; relationships to land, biological diversity, and so on; production (including technology choices); consumption (including what to produce); marketing (market access, quality protection and property rights); civil and political; economic, social and cultural; reproduction (including both human reproduction and biodiversity); and freedom of expression (language, culture, religion and arts) (these are modified from [37] (p. 389) (see also [38]). The workshop 
identified and listed rights in appropriate language under these headings (Table 2). There was no consensus about whether a Farmers' Rights instrument (in whatever form) should detail all the rights of farmers including those in other instruments, or only the rights that were specific to farmers. Perhaps this will depend on the forum eventually undertaking the negotiations? The substantial contribution from this workshop, however, was to develop and set out a list of possible substantive Farmers' Rights as a contribution and foundation for further consultations and negotiations.

Table 2. The possible substance of Farmers' Rights.

\begin{tabular}{|c|c|}
\hline Grouping & Right \\
\hline Livelihood & $\begin{array}{l}\text { The full enjoyment of all human rights and fundamental freedoms } \\
\text { The right to life, physical and mental integrity, liberty, and security of a person } \\
\text { The rights of women against discrimination in access: } \\
\text { To productive resources, including land } \\
\text { To work } \\
\text { To adequate housing } \\
\text { To programmes for social security, health, training and education } \\
\text { To economic opportunities through employment or self-employment } \\
\text { To credit and loans, marketing facilities and appropriate technology } \\
\text { To adequate living conditions, sanitation, electricity and water supply, transport and communications } \\
\text { The right to freedom of movement } \\
\text { The right to be protected from any work that is likely to be hazardous or to interfere with the family or } \\
\text { local community, including hazardous substances or toxic chemicals }\end{array}$ \\
\hline $\begin{array}{l}\text { Relationships to land, } \\
\text { biological diversity, } \\
\text { and so on }\end{array}$ & $\begin{array}{l}\text { The right to land, individually or collectively } \\
\text { The right to legal recognition for land tenure rights, including customary land tenure rights } \\
\text { The right to be protected against arbitrary and unlawful displacement from land or place of habitual } \\
\text { residence } \\
\text { The right to be protected against arbitrary and unlawful displacement from natural resources used in } \\
\text { farming and necessary for the enjoyment of adequate living conditions } \\
\text { The right to the conservation and protection of the environment and the productive capacity of their land } \\
\text { and other resources used and managed by farmers } \\
\text { The right to have access, use and management of land, water bodies, coastal seas, fisheries, pastures, and } \\
\text { forests used in farming and necessary for the enjoyment of adequate living conditions } \\
\text { The right to active and free participation in the preparation and implementation of policies, programmes, } \\
\text { and projects affecting resources including land and biological diversity } \\
\text { The right to Free, Prior, and Informed Consent } \\
\text { The right to seek, receive, develop, and impart an understanding and information about resources, } \\
\text { including land and biological diversity } \\
\text { The right to fair resolution of transboundary tenure issues } \\
\text { The right to fair, impartial, and appropriate evaluations and certifications of the quality of resources } \\
\text { including land and biological diversity } \\
\text { The right to equitably participate in sharing the benefits arising from the utilization of plant genetic } \\
\text { resources for food and agriculture } \\
\text { The right to participate in the making of decisions on matters relating to the conservation and sustainable } \\
\text { use of plant genetic resources for food and agriculture } \\
\text { The right to participate in the making of decisions on matters relating to the conservation and sustainable } \\
\text { use of plant genetic resources for food and agriculture } \\
\text { The right to save, use, exchange and sell farm-saved seeds and other propagating material } \\
\text { The right to compensation in cases of loss caused by the supply of bad seed, misinformation about seed } \\
\text { quality, and biopiracy }\end{array}$ \\
\hline $\begin{array}{l}\text { Production (including } \\
\text { technology choices) }\end{array}$ & $\begin{array}{l}\text { The right to have access, use, repair and management of the means of production including technologies } \\
\text { The right to active and free participation in the preparation and implementation of policies, programmes, } \\
\text { and projects affecting production, including technology choices } \\
\text { The right to seek, receive, develop, own, correct, and impart data and information about production, } \\
\text { including technology choices } \\
\text { The right to fair, impartial, and appropriate evaluations (including data and information) and } \\
\text { certifications of the quality of production, including technology choices }\end{array}$ \\
\hline
\end{tabular}


Table 2. Cont.

\begin{tabular}{|c|c|}
\hline Grouping & Right \\
\hline $\begin{array}{l}\text { Consumption } \\
\text { (including what } \\
\text { to produce) }\end{array}$ & $\begin{array}{l}\text { The right to have access, use, and management of the means of consumption including what to produce } \\
\text { The right to active and free participation in the preparation and implementation of policies, programmes, } \\
\text { and projects affecting consumption, including what to produce } \\
\text { The right to seek, receive, develop, own, correct, and impart data and information about consumption } \\
\text { including what to produce } \\
\text { The right to fair, impartial, and appropriate evaluations (including data and information) and } \\
\text { certifications of the quality of products, including technology choices }\end{array}$ \\
\hline $\begin{array}{l}\text { Marketing (market } \\
\text { access, quality } \\
\text { protection and } \\
\text { property rights) }\end{array}$ & $\begin{array}{l}\text { The right to have access, use, and management of the means of marketing including market access, } \\
\text { quality protection, and property rights } \\
\text { The right to active and free participation in the preparation and implementation of policies, programmes, } \\
\text { and projects affecting marketing, including market access, quality protection, and property rights } \\
\text { The right to seek, receive, develop, own, correct, and impart data and information about marketing, } \\
\text { including market access, quality protection, and property rights } \\
\text { The right to fair, impartial, and appropriate evaluations (including data and information) and } \\
\text { certifications of the quality about marketing, including market access, quality protection and } \\
\text { property rights }\end{array}$ \\
\hline Civil and political & $\begin{array}{l}\text { The right to life } \\
\text { The right to be free from arbitrary detention } \\
\text { The right to a fair trial } \\
\text { The freedoms of expression and association } \\
\text { The right to form and join trade unions } \\
\text { The right to participate in formulating and implementing development planning }\end{array}$ \\
\hline $\begin{array}{l}\text { Economic, social, } \\
\text { and cultural }\end{array}$ & $\begin{array}{l}\text { The right to food } \\
\text { The right to be free from hunger } \\
\text { The right to adequate housing } \\
\text { The right to health } \\
\text { The rights to water and sanitation } \\
\text { The right to education }\end{array}$ \\
\hline $\begin{array}{l}\text { Reproduction } \\
\text { (including both human } \\
\text { reproduction and } \\
\text { biodiversity) }\end{array}$ & $\begin{array}{l}\text { The right of all couples and individuals to decide the number, spacing and timing of their children } \\
\text { The right to sexual and reproductive health } \\
\text { The right of all to make decisions concerning reproduction free of discrimination, coercion, and violence } \\
\text { The right to be protected from any materials or products that are likely to be hazardous or to interfere } \\
\text { with the local community including hazardous substances or toxic chemicals } \\
\text { The right to determine on-farm reproduction of plant and animals including the technology used }\end{array}$ \\
\hline $\begin{array}{l}\text { Freedom of expression } \\
\text { (language, culture, } \\
\text { religion, and arts) }\end{array}$ & $\begin{array}{l}\text { The right to be free from all forms of violence } \\
\text { The right to the protection of traditional knowledge relevant to plant genetic resources for food and } \\
\text { agriculture } \\
\text { The right to promote and protect traditional knowledge, innovation, and practices } \\
\text { The right to enjoy culture and to freely pursue cultural development without interference or any form of } \\
\text { discrimination } \\
\text { The right to maintain, express, control, protect, and develop traditional and local knowledge } \\
\text { The right, individually or collectively, to express local customs, languages, culture, religions, literature, } \\
\text { and art }\end{array}$ \\
\hline
\end{tabular}

\section{Conclusions}

In final words, we hope that the work and effort put into dealing with Farmers' Rights both within the formal ITPGRFA forums and by institutions and individuals contributing to realising Farmers' Rights can deliver justice and equity for farmers through national governments. This report outlines a framework for realising the substance of Farmers' Rights. By identifying the possible substance of Farmers' Rights, future work can more reasonably set out in appropriate rights language the substance of Farmers' Rights for implementation in national legislation. This will, of course, require appropriate consultations and negotiations that are beyond our remit and competence. 
Author Contributions: Conceptualisation, E.B., C.L. and K.T.; writing—original draft, E.B. and C.L.; writing-review and editing, K.A., E.B., X.C., S.C., F.H., H.J., E.K., C.L., J.M., D.R., M.R., J.S. and K.T. All authors have read and agreed to the published version of the manuscript.

Funding: This research received no external funding.

Institutional Review Board Statement: Not applicable.

Informed Consent Statement: Not applicable.

Data Availability Statement: Not applicable.

Conflicts of Interest: The authors declare no conflict of interest.

\section{References}

1. Governing Body of the International Treaty on Plant Genetic Resources for Food and Agriculture. Collection of Views and Experiences Submitted by Contracting Parties and other Relevant Organizations on the Implementation of Article 9; IT/GB-3/09/Inf.6 Add.1; FAO: Rome, Italy, 2009.

2. Governing Body of the International Treaty on Plant Genetic Resources for Food and Agriculture. Collection of Views and Experiences Submitted by Contracting Parties and other Relevant Organizations on the Implementation of Article 9; IT/GB-3/09/Inf.6; FAO: Rome, Italy, 2009.

3. Commission on Genetic Resources for Food and Agriculture. The Second Report on The State of the World's Plant Genetic Resources for Food and Agriculture; FAO: Rome, Italy, 2015.

4. Governing Body of the International Treaty on Plant Genetic Resources for Food and Agriculture. Eighth Session of the Governing Body of the International Treaty on Plant Genetic Resources for Food and Agriculture; IT/GB-8/19/Report; FAO: Rome, Italy, 2019.

5. Governing Body of the International Treaty on Plant Genetic Resources for Food and Agriculture. Seventh Session of the Governing Body of the International Treaty on Plant Genetic Resources for Food and Agriculture; IT/GB-7/17/Report; FAO: Rome, Italy, 2017.

6. Governing Body of the International Treaty on Plant Genetic Resources for Food and Agriculture. Sixth Session of the Governing Body of the International Treaty on Plant Genetic Resources for Food and Agriculture; IT/GB-6/15/Report; FAO: Rome, Italy, 2015.

7. Governing Body of the International Treaty on Plant Genetic Resources for Food and Agriculture. Fifth Session of the Governing Body of the International Treaty on Plant Genetic Resources for Food and Agriculture; IT/GB-5/13/Report; FAO: Rome, Italy, 2013.

8. Governing Body of the International Treaty on Plant Genetic Resources for Food and Agriculture. Fourth Session of the Governing Body of the International Treaty on Plant Genetic Resources for Food and Agriculture; IT/GB-4/11/Report; FAO: Rome, Italy, 2011.

9. FAO. Ad Hoc Technical Expert Group on Farmers' Rights. In Report of the Second meeting of the Ad-Hoc Technical Expert Group on Farmers' Rights; IT/GB-8/AHTEG-FR-2/19/Report; FAO: Rome, Italy, 2019.

10. FAO. Ad-Hoc Technical Expert Group on Farmers' Rights. In Options for encouraging, guiding and promoting the realization of Farmers' Rights as set in Article 9 of the International Treaty; IT/GB-8/AHTEG-FR-2/19/4 Rev.1; FAO: Rome, Italy, 2019.

11. Correa, C. Implementing Farmers' Rights Relating to Seeds; Research Paper 75; South Centre: Geneva, Switzerland, 2017.

12. Rose, G. International Law in the 21st Century: The International Treaty on Plant Genetic Resources for Food and Agriculture. Int Envtl. L. Rev. 2003, 15, 583-603.

13. Lawson, C. Implementing Farmers' Rights: Finding Meaning and Purpose for the International Treaty on Plant Genetic Resources for Food and Agriculture Commitments? Eur. Intellect. Prop. Rev. 2015, 37, 442-454.

14. Governing Body of the International Treaty on Plant Genetic Resources for Food and Agriculture. First Session of the Governing Body of the International Treaty on Plant Genetic Resources for Food and Agriculture; IT/GB-1/06/Report; FAO: Rome, Italy, 2006.

15. Governing Body of the International Treaty on Plant Genetic Resources for Food and Agriculture. Second Session of the Governing Body of the International Treaty on Plant Genetic Resources for Food and Agriculture; IT/GB-2/07/Report; FAO: Rome, Italy, 2007.

16. Governing Body of the International Treaty on Plant Genetic Resources for Food and Agriculture. Third Session of the Governing Body of the International Treaty on Plant Genetic Resources for Food and Agriculture; IT/GB-3/09/Report; FAO: Rome, Italy, 2009.

17. Governing Body of the International Treaty on Plant Genetic Resources for Food and Agriculture. Report on Actions Taken by the Secretary on the Implementation of the Funding Strategy; IT/GB-3/09/8; FAO: Rome, Italy, 2009.

18. Governing Body of the International Treaty on Plant Genetic Resources for Food and Agriculture. Report by the Bureau on the First Project Cycle of the Benefit-sharing Fund; IT/GB-3/09/Inf.11; FAO: Rome, Italy, 2009.

19. Governing Body of the International Treaty on Plant Genetic Resources for Food and Agriculture. Report on the Benefit-sharing Fund: 2016-2017; IT/GB-7/17/Inf.5; FAO: Rome, Italy, 2017.

20. Governing Body of the International Treaty on Plant Genetic Resources for Food and Agriculture. Report on the Execution of the Project Cycle of the Benefit-Sharing Fund since the Fifth Session of the Governing Body; IT/GB-6/15/Inf.04; FAO: Rome, Italy, 2015.

21. FAO. Ad Hoc Technical Expert Group on Farmers' Rights. Report of the First Meeting of the Ad Hoc Technical Expert Group on Farmers' Rights; IT/GB-8/AHTEG-FR-1/18/Report; FAO: Rome, Italy, 2018.

22. Berge, G.; Andersen, R. Informal International Consultation on Farmers Rights; Norway Ministry of Agriculture and Food: Oslo, Norway, 2007. 
23. Governing Body of the International Treaty on Plant Genetic Resources for Food and Agriculture. Global Consultations on Farmers' Rights in 2010; IT/GB-4/11/Circ.1; FAO: Rome, Italy, 2011.

24. FAO. Global Consultation on Farmers' Rights. In Summary of Presentations and Discussions; FAO: Rome, Italy, 2016.

25. Governing Body of the International Treaty on Plant Genetic Resources for Food and Agriculture. Proceedings of the Global Consultation on Farmers' Rights; IT/GB-7/17/Inf.10; FAO: Rome, Italy, 2017.

26. Governing Body of the International Treaty on Plant Genetic Resources for Food and Agriculture. Submission from Norway and Indonesia containing the Co-Chairs proposal from the Global Consultation on Farmers' Rights; IT/GB-7/17/Circ.1; FAO: Rome, Italy, 2017.

27. FAO. Stakeholders' Consultation on Farmers' Rights. In African Position Paper; FAO: Rome, Italy, 2016.

28. Quaker United Nations Office. Summary Report of the Stakeholder Consultation on Implementation of Farmers' Rights; Quaker United Nations Office: Geneva, Switzerland, 2016.

29. Governing Body of the International Treaty on Plant Genetic Resources for Food and Agriculture. Results of the Online Consultation to Gather Views and Needs on the Implementation of Farmers' Rights; IT/GB-7/17/Inf.11; FAO: Rome, Italy, 2017.

30. Governing Body of the International Treaty on Plant Genetic Resources for Food and Agriculture. Proceedings of the Symposium on Possible Interrelations between the International Treaty on Plant Genetic Resources for Food and Agriculture and the International Convention for the Protection of New Varieties of Plants; IT/GB-7/17/Inf.14; FAO: Rome, Italy, 2017.

31. FAO. Ad Hoc Technical Expert Group on Farmers' Rights. In Reports from the Stakeholders' Consultations; IT/GB-8/AHTEG-FR1/18/Inf.5; FAO: Rome, Italy, 2018.

32. Commission on Human Rights. Sub-Commission on Prevention of Discrimination and Protection of Minorities. In Human Rights of Indigenous Peoples: Report of the Technical Meeting on the Protection of the Heritage of Indigenous People; E/CN.4/Sub.2/1997/15; UN: New York, NY, USA, 1997.

33. Food and Agriculture Organisation of the United Nations. Report of the Conference of FAO; Twenty-fifth Session (C 1989); FAO: Rome, Italy, 1989.

34. Adhikari, K. Farmers' Rights: Global Contexts, Negotiations and Strategies; Policy Brief No. 18; SAWTEE: Kathmandu, Nepal, 2009.

35. Claeys, P. Human Rights and the Food Sovereignty Movement: Reclaiming Control; EarthScan: Abingdon, VA, USA, 2015.

36. Human Rights Council. Final Study of the Human Rights Council Advisory Committee on the Advancement of the Rights of Peasants and Other People Working in Rural Areas; A/HRC/19/75; UN: New York, NY, USA, 2012.

37. Claeys, P. The Rise of New Rights for Peasants. From Reliance on NGO Intermediaries to Direct Representation. Transnatl. Leg. Theory 2018, 9, 386-399.

38. Purwanto, H. Local to Global: How Serikat Petani Indonesia Has Accelerated the Movement for Agrarian Reform. In La Via Campesina, La Via Campesina's Open Book: Celebrating 20 Years of Struggle and Hope. 2013. Available online: https://viacampesina. org/en/wp-content/uploads/sites/2/2013/05/EN-13.pdf (accessed on 17 February 2021).

\section{Short Biography of Authors}

Dr. Kamalesh Adhikari is a Research Fellow, ARC Training Centre for Uniquely Australian Foods and Member, ARC Laureate Project 'Harnessing Intellectual Property to Build Food Security' at the TC Beirne School of Law, The University of Queensland, Australia.

Dr. Edwin Bikundo is a Senior Lecturer and member of the Law Futures Center at the Griffith Law School, Griffith University, Australia.

Dr. Xan Chacko is a Mellon Postdoctoral Fellow in Women's and Gender Studies at Wellesley College, Massachusetts, USA.

Dr. Susannah Chapman is an ARC DECRA Fellow in the School of Social Science, The University of Queensland, Australia.

Dr. Fran Humphries is a Research Fellow at the School of Law, Queensland University of Technology, Australia.

Dr. Hope Johnson is a Lecturer in law at the School of Law, Queensland University of Technology, Australia.

Evan Keast is studying International Relations in the Faculty of Humanities and Social Sciences, University of Queensland, Australia.

Dr. Charles Lawson is a Professor and member of the Law Futures Centre at the Griffith Law School, Griffith University, Australia.

Dr. Justin Malbon is an Adjunct Professor at the Griffith Law School, Griffith University, Australia.

Dr. Daniel Robinson is a Professor in Environment and Society, Arts and Social Sciences Faculty, and Academic Lead for the Pacific for the Institute for Global Development (IGD), at the University of New South Wales, Australia.

Dr. Michelle Rourke is a CSIRO Synthetic Biology Future Science Fellow at the Law Futures Centre, Griffith University, Australia.

Dr. Jay Sanderson is a Professor at the School of Law and Criminology, University of the Sunshine Coast, Australia.

Dr Kieran Tranter is the Professor of Law, Technology and the Future at the School of Law, Queensland University of Technology, Australia. 